Встановлено, що анодна обробка олова у лужному розчині з добавкою $\mathrm{K}_{2} \mathrm{TiO}_{3}$ дозволяе одержувати плівки $\mathrm{SnO}_{x}\left(\mathrm{TiO}_{y}\right)$ з вмістом сполук титану до 14-15\% (мол.). Корозійна стійкість плівок $\mathrm{SnO}_{x}\left(\mathrm{TiO}_{y}\right)$ в 10 разів перевищує стійкість немодифікованих зразків. Показана висока електрокаталітична активність модифікованих оксидних плівок на олові. Встановлено механізм анодного окиснення метил-трет-бутилового ефіру на модифікованих оксидних плівках на олові

Ключові слова: модифіковані оксидні плівки, оксидні сполуки титана, олово, корозійна стійкість, електрокаталітична активність

Установлено, что анодная обработка олова в щелочном растворе с добавкой $\mathrm{K}_{2} \mathrm{TiO}_{3}$ позволяет получить пленки $\mathrm{SnO}_{x}\left(\mathrm{TiO}_{y}\right)$ с содержанием соединений титана до 14-15\% (мол.). Коррозионная стойкость пленок $\mathrm{SnO}_{x}\left(\mathrm{TiO}_{y}\right)$ в 10 раз превышает стойкость немодифицированных образцов. Показана высокая электрокаталитическая активность модифицированных оксидных пленок на олове. Установлен механизм анодного окисления метил-третбутилового әфира на модифицированных оксидных пленках на олове

Ключевые слова: модифицированные оксидные пленки, оксидные соединения титана, олово, коррозионная стойкость, әлектрокаталитическая активность

\section{RESEARCH INTO CORROSION AND ELECTROCATALYTIC PROPERTIES OF THE MODIFIED OXIDE FILMS ON TIN}

K. PIy a sovskay a

$\mathrm{PhD}$, Associate Professor*

V. Vargal y u k

Doctor of Chemical Sciences, Professor*

E-mail: Chemistry.dnu@gmail.com

I. S k n a r

$\mathrm{PhD}$, Associate Professor Department of Processes, Devices and General Chemical Technology** E-mail: juventa2011@gmail.com

A. Cherem y sinova

$\mathrm{PhD}$, Associate Professor Department of Processes, Apparatus and

General Chemical Technology**

E-mail: Anna_Sokol_@i.ua

0. Sigu nov

$\mathrm{PhD}$, Associate Professor

Department of Chemical Technology of Astringent Materials**

E-mail: alsigunov@ukr.net

A. Karakurkchi

$\mathrm{PhD}$, Head of Research Laboratory

Research Laboratory

National Technical University "Kharkiv Polytechnic Institute"

Kyrpychova str., 2, Kharkiv, Ukraine, 61002

E-mail: anyutikukr@gmail.com

*Department of Physical and Inorganic Chemistry

Oles Honchar Dnipropetrovsk National University

Gagarina ave., 72, Dnipro, Ukraine, 49010

**Ukrainian State University of Chemical Technology

Gagarina ave., 8, Dnipro, Ukraine, 49005

\section{Introduction}

Anodic treatment of galvanic tin coating in alkaline solutions is one of the most controllable and effective ways for the passivation of tin. The oxide film formed in this way has a high degree of continuity and provides reliable protection of tin from corroding effect of the environment. An important task is the passivation of tin coatings of steel packaging in the food industry. A third of tin used in the world accounts for the production of tinned sheet [1]. Chemical passivation of tin coatings is typically performed in solutions that contain chrome-containing compounds. Toxic hexavalent chromium oxoanions get into composition of the obtained film. Despite subsequent varnishing, such coating is not environmentally safe. At the same time, electrochemical passivation of the tinned packaging guarantees ecological aspect of protective film with a high corrosion resistance of the oxide layer.

Electrochemical method is employed to receive oxide films for catalysts and gas sensors. Tin dioxide is used as electrocatalyst. Tin monoxide displays photocatalytic properties. Anodic treatment of tin coatings makes it possible to vary the composition of the formed oxide mixture with a high degree of accuracy.

It should be noted that rather important characteristics of oxide films used as catalysts include chemical resistance to the impact of environment. This factor affects the service life of a catalyst. Improving performance characteristics of oxide layers on tin can be achieved through doping these films with oxides of other metals. In this connection, a relevant task is to establish corrosive and catalytic properties of the modified oxide films on tin. 


\section{Literature review and problem statement}

Salts of tin belong to non-toxic, which allows using tin coatings for the protection of steel containers of food products from corrosion. A slowdown in the rate of dissolving the protective tin coating under the influence of aggressive medium is provided by an oxide film formed on the surface of tin [2]. The composition and structure of oxide film on tin depend on the conditions of its formation. Passive film on tin, anodically formed in a citrate buffer solution, consists of three layers [3]. Inner layer of small thickness is a tin monoxide. Quite thick intermediate layer consists of tin dioxide. The outer layer is a tetravalent tin hydroxide. Protective properties of oxide film are determined by the composition and structure. Inner oxide layer is characterized by a high degree of defect structure and is low-stable [4]. The formation of protective layer of tin dioxide occurs during oxidation of the metal [5]. Post-oxidation of tin monoxide appears to be unlikely [6]. The presence of tartaric acid in the solution that is in contact with the passivated tin surface contributes to the accelerated dissolution of metal and reduces protective effect of a tin dioxide film [1]. However, anodic treatment of tin in a citrate buffer solution leads to the formation of a passive film, which consists of a slightly-soluble polymeric complex of tin(II) ions with citrate ions [7].

Anodic treatment of tin coatings in alkaline medium, depending on the magnitude of potential, leads to the formation of various oxides of tin [8]. In the $\mathrm{NaOH}$ solution, at a potential of $-0.9 \mathrm{~V}$, the white residue $\mathrm{SnO} \cdot \mathrm{nH}_{2} \mathrm{O}$ forms, which possesses a weak protective effect. The offset of electrode potential to a positive side leads to the formation of micro dimensional crystals of $\mathrm{SnO}$. In the region of potentials that are more positive than $-0.7 \mathrm{~V}$, the $\mathrm{SnO}_{2}$ films form, which provide tin coatings with reliable protection against corrosion. In [9], the authors studied the anodic behavior of tin electrode in $0.1 \mathrm{~mol} / \mathrm{K} \mathrm{KOH}$. The regions of potentials were established, in which compounds of tin with varying degrees of oxidation are formed. The presence of tin monoxide reduces corrosion resistance of the passive film obtained during anodic treatment of tin. Dissolution of $\mathrm{SnO}$ in corrosive medium leads to crack formation in the oxide layer [9]. In order to extend lifecycle of the tinned products, it is necessary to solve this problem by modifying the protective anode films.

Electrochemical method of the formation of oxide films on tin in alkaline solutions is employed to obtain catalysts. Thus, anodic polarization of tin in the electrolyte containing $0.125-1 \mathrm{~mol} / 1$ of $\mathrm{NaOH}$, at a potential of $5-15 \mathrm{~V}$, made it possible to synthesize the nanoporous catalyst $\mathrm{SnO}_{2}$ with a specific surface of $79.6 \mathrm{~m}^{2} / \mathrm{g}$ [10]. In [11], the authors investigated effect of the anodic tin treatment conditions on the composition, morphology, and structure of oxide films. The authors of [12] synthesized the $\mathrm{SnO}$ anodic films from an alkaline electrolyte. It is shown that a slight deviation in the ratio of oxide elements form the stoichiometric predetermines photocatalytic activity of films in the visible range of radiation.

Improving the physical-chemical properties of coatings with individual substances is possible through the deposition of alloys [13] and composites [14-16]. In the case of oxides, in order to enhance catalytic activity and corrosion resistance, the modification of films by the oxides of other metals, by metal nanoparticles, or by certain ions is applied. In [17], a new electrode material is proposed for the electro- oxidation of formaldehyde. The improved catalytic activity is ensured by the platinum nanoparticles implanted into an indium-tin oxide. High corrosion resistance in a wide range of potentials is demonstrated by the tin oxide, doped with fluoride ions [18]

Therefore, substantial demand for protective and catalytic properties of anodic films of tin oxides predetermines the search for new techniques to improve the functional characteristics of such materials. The high cost of platinum group metals and high toxicity of fluoride ions stimulates research into modification of anodic films by ecologically clean and catalytically active dopants. In this regard, it is important to explore corrosive and catalytic properties of oxide films on tin, modified by titanium dioxide. The possibility for the synthesis of such films is shown in [19].

\section{The aim and objectives of the study}

The aim of present work is to study corrosive and electrocatalytic properties of the modified oxide films on tin. This will make it possible to create a new technology for the anodic formation of corrosion-resistant electrocatalysts on the surface of galvanic tin coatings.

To achieve the set aim, the following tasks have been solved:

- to derive dependences of composition of the anodic films on tin, obtained in the presence of potassium metatitanate, and to estimate the effect of oxide compounds of titanium on the corrosion resistance of coatings;

- to study electrocatalytic properties of the modified oxides on tin and to reveal the mechanism of anodic oxidation of methyl tert-butyl ether on the oxide films.

\section{Materials and methods for examining the composition, corrosive and electrocatalytic properties of the modified tin oxides}

Oxide films were formed during anodic treatment of the tin electrode in the $\mathrm{KOH}$ solutions. We used potassium metatitanate as the modifying additive. The concentrate of potassium metatitanate was synthesized by using potassium hydroxide and titanium dioxide in the anatase modification. Prepared concentrate contained $0.13 \mathrm{~mol} / 1$ of $\mathrm{K}_{2} \mathrm{TiO}_{3}$ and $2.8 \mathrm{~mol} / \mathrm{l}$ of $\mathrm{KOH}$.

The concentration of titanium(IV) in the starting concentrate and in the anodic films was determined by a spectrophotometric method. Colored solutions of titanium(IV) compounds with hydrogen peroxide in acidic medium were analyzed using the spectrophotocolorimeter K-2M (Russia). Calibration chart (Fig. 1) was built using a standard solution containing $1 \mathrm{~g} / \mathrm{l}$ of $\mathrm{Ti}^{4+}$. The measurements were conducted at a wavelength of $400 \mathrm{~nm}$, in the cuvette with a thickness of $1 \mathrm{~cm}$.

When determining the content of titanium (IV) in the oxide films of a coating, we dissolved in the single-molar sulfuric acid. Then we added to this solution a 3-\% solution of hydrogen peroxide with the volume brought to the mark by bidistilled water.

Determining the content of tin oxides with a different oxidation degree was conducted in line with the original methodology using coulometry [20]. Electrochemically-formed oxide film on tin was cathodically reduced in 
the solution containing $0.01 \mathrm{~mol} / \mathrm{l}$ of $\mathrm{KCl}$ and phosphate buffer. Oxygen-containing compounds of titanium under these conditions are not reduced. The measurements were carried out in a standard three-electrode cell using the pulse potentiostat PI-50-1.1 (Belarus) and the programmer PR-8 (Belarus).

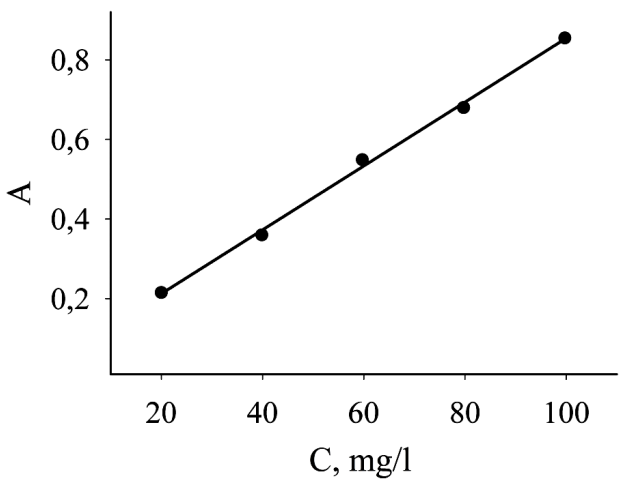

Fig. 1. Dependence of optical density of standard solutions on concentration. $\left[\mathrm{TiO} \cdot \mathrm{H}_{2} \mathrm{O}_{2}\right]^{2+}$

Corrosion resistance of the oxide films on tin was estimated by the method of registration of self-activation curves. The essence of the method is in determining a period during which a potential of the oxidized tin electrode reverts to the value, characteristic for pure metal. Values of the potential were registered using the two-coordinate potentiometer N-307/1 (Belarus). Self-activation curves were derived in the $0.5 \mathrm{M}$ solution of $\mathrm{KOH}$. All potentials are given relative to a normal hydrogen electrode.

Concentration values of methyl tert-butyl ether (MTBE) were determined using the gas-liquid chromatograph Chrom-5 (Czech Republic). An analysis was conducted under the following conditions. We used as a fixed liquid phase polyethylene glycol on a solid carrier-chemisorb with a particle diameter of $0.2 \mathrm{~mm}$. Argon was used as a carrier gas. The temperature stood at $75^{\circ} \mathrm{C}$, pressure at the inlet to the column was equal to $1.8 \mathrm{~atm}$.

Research into morphology of the $\mathrm{SnO}_{x}\left(\mathrm{TiO}_{y}\right)$ precipitation surface was carried out using the raster electron microscope REMMA 102-02 (Ukraine).

\section{Results of research into composition and corrosive properties of the modified oxide films}

A significant advantage when obtaining oxide films by an electrochemical method is high process controllability and the possibility of variation in the ratios of oxygen compounds of titanium and tin in films.

Electrochemical formation of the mixed oxide layer of $\mathrm{SnO}_{\mathrm{x}}\left(\mathrm{TiO}_{\mathrm{y}}\right)$ on the surface of tin was performed in the alkaline electrolyte containing potassium metatitanate. A choice of titanium-containing compound is predetermined by the fact that potassium metatitanate is stable in alkaline medium. Anodic treatment of tin surface was conducted in electrolytes with an alkali content from 0.1 to $1.0 \mathrm{~mol} / \mathrm{l}$, titanium-containing additive - from $0.1 \cdot 10^{-3}$ to $5.0 \cdot 10^{-3} \mathrm{~mol} / \mathrm{l}$. Anodic tin oxidation was carried out using a single-stage and the two-stage techniques [20]. At a single-stage anodic treatment of tin surface, a potential of the electrode was $3.0 \mathrm{~V}$. A two-stage treatment involved sequential polariza- tion of the anode at a potential of $-0.3 \mathrm{~V}$ and $3.0 \mathrm{~V}$. Processing period at each potential ranged from 5 to 40 seconds. The surface concentration of Ti(IV) and Sn(IV) in the anodic films is in the range of $10^{-8}-10^{-6} \mathrm{~mol} / \mathrm{cm}^{2}$. Table 1 gives values of the $\mathrm{Ti}(\mathrm{IV})$ and $\mathrm{Sn}(\mathrm{IV})$ ratios in the oxide films obtained from alkaline solutions with a content of $\mathrm{TiO}_{3}^{2-}$ ions equal to $10^{-3} \mathrm{~mol} / \mathrm{l}$.

Table 1

Ratio of the Ti(IV) and Sn(IV) concentrations in the $\mathrm{SnO}_{x}\left(\mathrm{TiO}_{y}\right)$ films

\begin{tabular}{|c|c|c|c|c|}
\hline \multirow{2}{*}{$\begin{array}{c}\mathrm{C}_{\mathrm{KOH}}, \\
\mathrm{mol} / 1\end{array}$} & \multicolumn{4}{|c|}{ Electrolysis time, $\mathrm{s}$} \\
\cline { 2 - 5 } & \multicolumn{2}{|c|}{ single-stage treatment } & \multicolumn{2}{c|}{ two-stage treatment } \\
\cline { 2 - 5 } & 20 & 50 & $5 ; 15$ & $10 ; 40$ \\
\hline 0.1 & $1.5 / 18.0$ & $2.3 / 35.7$ & $2.6 / 11.5$ & $6.4 / 36.7$ \\
\hline 0.5 & $2.3 / 20.1$ & $5.2 / 31.3$ & $7.2 / 17.7$ & $7.5 / 34.5$ \\
\hline
\end{tabular}

Increasing the time of anodic treatment under a single-stage mode leads to an increase in the content of tin and titanium oxides in the film. A similar pattern can be observed in the case of a two-stage treatment mode. However, sequential anodic treatment of the tin electrode at potentials 0.3 and $3.0 \mathrm{~V}$ contributes to a substantial increase in the content of titanium compounds in the film. This pattern takes place regardless of the concentration of potassium hydroxide in the electrolyte.

It should be noted that at an overall time of the electrolysis of $20 \mathrm{~s}$, during transition to the two-stage mode of anodic treatment, there is a decrease in the concentration of $\mathrm{Sn}(\mathrm{IV})$ in the film.

Content of the Ti(IV) compounds in the surface oxide film depends on the concentration of $\mathrm{TiO}_{3}^{2-}$ ions in the electrolyte and the period of anodic treatment of tin electrode (Table 2).

Table 2

Dependence of the Ti(IV) content $\left(10^{8} \mathrm{~mol} / \mathrm{cm}^{2}\right)$ in the $\mathrm{SnO}_{x}\left(\mathrm{TiO}_{y}\right)$ film on the concentration of titanate ions in the electrolyte

\begin{tabular}{|c|c|c|c|c|}
\hline \multirow{2}{*}{$\begin{array}{c}\text { Elec- } \\
\text { trolysis } \\
\text { time, } \mathrm{s}\end{array}$} & 0.5 & 1.0 & 2.0 & 20.0 \\
\cline { 2 - 5 } & $\begin{array}{c}1.13 \\
\mathrm{C}\end{array}$ & $\begin{array}{c}2.26 \\
\mathrm{Ti}(\mathrm{IV})\end{array}$ & $10^{3}, \mathrm{~mol} / \mathrm{l}$ \\
\hline 20 & $(6.2 \%, \mathrm{~mol})$ & $(10.1 \%, \mathrm{~mol})$ & $(10.5 \%, \mathrm{~mol})$ & $(8.5 \%, \mathrm{~mol})$ \\
\hline 50 & $\begin{array}{c}2.32 \\
(7.4 \%, \mathrm{~mol})\end{array}$ & $\begin{array}{c}5.21 \\
(14.3 \%, \mathrm{~mol})\end{array}$ & $\begin{array}{c}5.75 \\
(14.6 \%, \mathrm{~mol})\end{array}$ & $\begin{array}{c}5.90 \\
(14.0 \%, \mathrm{~mol})\end{array}$ \\
\hline 300 & $\begin{array}{c}2.55 \\
(6.9 \%, \mathrm{~mol})\end{array}$ & $\begin{array}{c}6.53 \\
(13.8 \%, \mathrm{~mol})\end{array}$ & $\begin{array}{c}6.70 \\
(14.7 \%, \mathrm{~mol})\end{array}$ & $\begin{array}{c}6.89 \\
(15.2 \%, \mathrm{~mol})\end{array}$ \\
\hline
\end{tabular}

Increasing the concentration of titanate ions in the electrolyte from $1.0 \cdot 10^{-3} \mathrm{~mol} / \mathrm{l}$ to $20.0 \cdot 10^{-3} \mathrm{~mol} / \mathrm{l}$ leads to a certain decrease in the content of $\mathrm{Ti}(\mathrm{IV})$ in the surface oxide. A change in the time of anodic treatment from $50 \mathrm{~s}$ to $300 \mathrm{~s}$ also contributes to an increase in the content of Ti(IV) in the oxide film. Thus, by varying the electrolyte composition and the anodic treatment parameters, it is possible to form on the surface of tin the $\mathrm{SnO}_{x}\left(\mathrm{TiO}_{\mathrm{y}}\right)$ films with the specified quantitative composition.

Noteworthy is the absence of symbasis in a change in the surface concentration and percentage of Ti(IV). This is apparently due to the fact that a certain amount of titanate ions and stannate ions penetrate the films. Consequently, 
there is an imbalance in a change in the molar content and percentage of $\mathrm{Ti}(\mathrm{IV})$ in the film.

Study into the $\mathrm{SnO}_{\mathrm{x}}\left(\mathrm{TiO}_{\mathrm{y}}\right)$ surface morphology revealed that titanium compounds did not form a separate phase (Fig. 2). The surface of the sample is homogeneous and finegrained. This is apparently due to the fact that the oxide film contains a solid replacement solution of tin titanate and stannate.

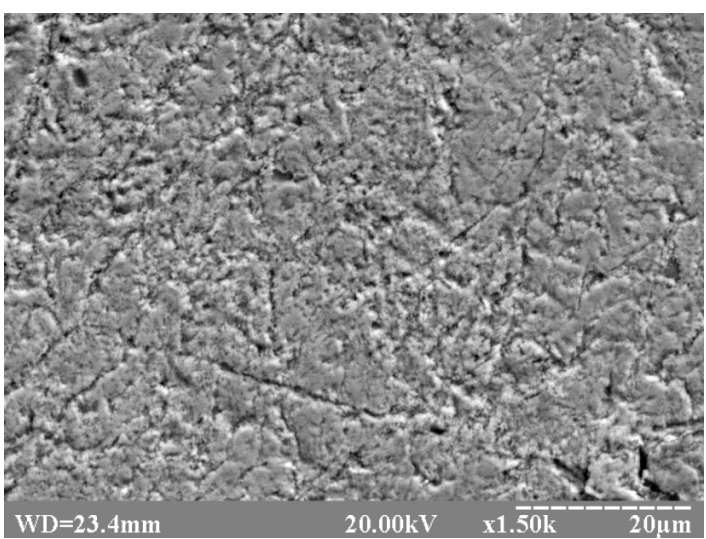

Fig. 2. Microphotograph of the $\mathrm{SnO}_{x}\left(\mathrm{TiO}_{\mathrm{y}}\right)$ film surface containing $5.21 \cdot 10^{-8} \mathrm{~mol} / \mathrm{cm}^{2}$ of $\mathrm{Ti}(\mathrm{IV})$

Oxide films on tin, modified by oxide compounds of titanium(IV), possess enhanced corrosion resistance. Table 3 shows that the time of self-activation of tin samples with such films exceeds that of the tin oxides by several times.

Table 3

Time of self-activation of $\mathrm{SnO}_{x}\left(\mathrm{TiO}_{\mathrm{y}}\right)$ in $0.5 \mathrm{~mol} / \mathrm{l}$ of the $\mathrm{KOH}$ solution depending on the concentration of titanate and alkali in the electrolyte of film formation

\begin{tabular}{|c|c|c|c|c|}
\hline \multirow{2}{*}{$\begin{array}{c}\mathrm{C}_{\mathrm{KOH}}, \\
\mathrm{mol} / \mathrm{l}\end{array}$} & \multicolumn{4}{|c|}{$\mathrm{C}_{\mathrm{V}}\left(\mathrm{TiO}_{3}^{2-}\right) \cdot 10^{3}, \mathrm{~mol} / \mathrm{l}$} \\
\cline { 2 - 5 } & 0 & 0.5 & 1.0 & 2.0 \\
\hline 0.1 & 93 & 170 & 930 & 1010 \\
\hline 0.5 & 99 & 1270 & 1850 & 1920 \\
\hline
\end{tabular}

Thus, when adding $1 \cdot 10^{-3} \mathrm{~mol} / \mathrm{l}$ of potassium metatitanate to $0.1 \mathrm{~mol} / \mathrm{l}$ of the $\mathrm{KOH}$ solution, corrosion resistance of $\mathrm{SnO}_{\mathrm{x}}\left(\mathrm{TiO}_{\mathrm{y}}\right)$ increases 10 times in comparison with the $\mathrm{SnO}_{\mathrm{x}}$ films. With an increase in the concentration of alkali in electrolyte for the formation of oxide films, difference in the corrosion resistance grows twenty-fold. Thus, using the addition of $\mathrm{K}_{2} \mathrm{TiO}_{3}$ in electrolyte for the anodic treatment of tin surface makes it possible to improve significantly corrosion resistance of the oxide film.

\section{Discussion of results of research into electrocatalytic properties of the modified oxide films on tin}

The mixtures of tin and titanium oxides, obtained by physical-chemical methods, exhibit high electrocatalytic activity relative to certain oxidative reactions. Electrocatalytic properties of the $\mathrm{SnO}_{x}\left(\mathrm{TiO}_{\mathrm{y}}\right)$ films were investigated for the reaction of electrochemical oxidation of MTBE in the $\mathrm{KOH}$ solutions with a concentration from 0.1 to $1.0 \mathrm{~mol} / 1$.
Dependences of a change in the ether concentration on the time of electrooxidation at a potential of $3.0 \mathrm{~V}$ are shown in Fig. 3. In the presence of oxygen compounds of titanium in the composition of a surface film, the MTBE degradation process is accelerated. In this case, an increase in the content of Ti(IV) in the film leads to the increased electrocatalytic effect.

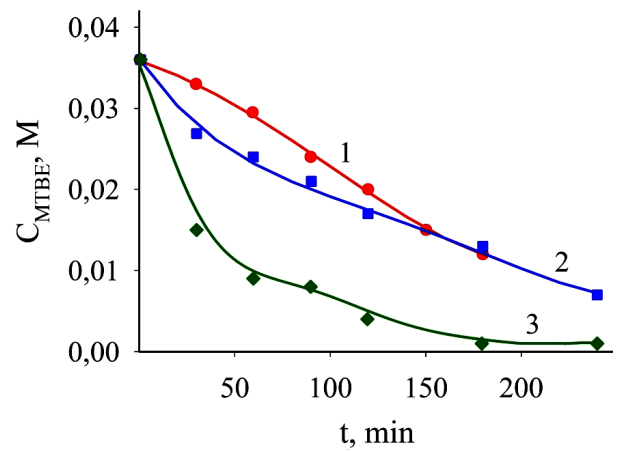

Fig. 3. Dependence of MTBE concentration on the time of electrooxidation in the $0.5 \mathrm{M}$ solution of $\mathrm{KOH}$ on the oxide films containing $\mathrm{Ti}(\mathrm{IV}), \mathrm{mol} / \mathrm{cm}^{2}: 1-0 ; 2-2.26 \cdot 10^{-8}$;

$$
3-5.21 \cdot 10^{-8}
$$

An increase in the content of Ti(IV) compounds in an oxide film contributes to the growing degree of MTBE decomposition. This dependence is linear in nature. It can be attributed to the primary adsorption of MTBE molecules on the sections of anode that contains the Ti(IV) compounds. This is possible if the adsorbed MTBE molecules undergo electrodestruction directly on the surface of an oxide film.

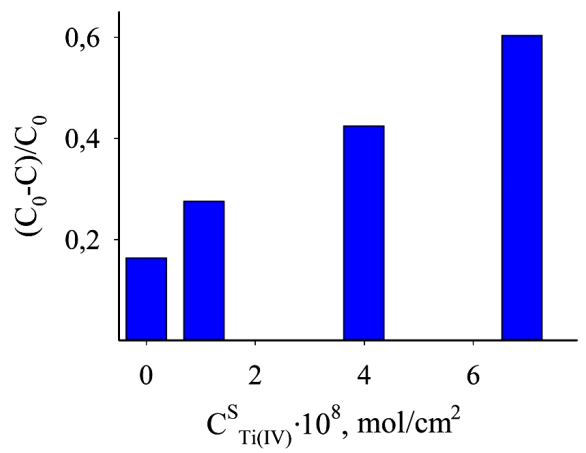

Fig 4. Dependence of the MTBE decomposition degree on the concentration of $\mathrm{Ti}(\mathrm{IV})$ compounds in an oxide film on tin electrode. Duration of MTBE electrooxidation is $30 \mathrm{~min}$

This, to some extent, can be confirmed by the character of dependence of the total anode current on the time of MTBE electrooxidation (Fig. 5). Should the oxidation of ether proceed as a result of interaction with oxygen radicals, then the presence of MTBE in the solution would have led to an increase in the total current. This is predetermined by the offset of equilibrium in the oxygen-generating reaction. In practice, there is another dependence. Apparently, more realistic is the direct oxidation of MTBE molecules on the anode and oxygen-generating reaction inhibition by the adsorbed products of ether decomposition.

Worth paying attention to is the specific character of dependence of the total current on the electrolysis time proceeding on the film with a maximum content of Ti(IV) (Fig. 5, curve 3). After 150 minutes of the electrolysis, the 
total current rises and reaches constant value. According to data in Fig. 3, this time corresponds to the almost complete decomposition of MTBE. The constant current value matches the balance between a surface concentration of the MTBE degradation products and their volumetric content in the electrolyte.

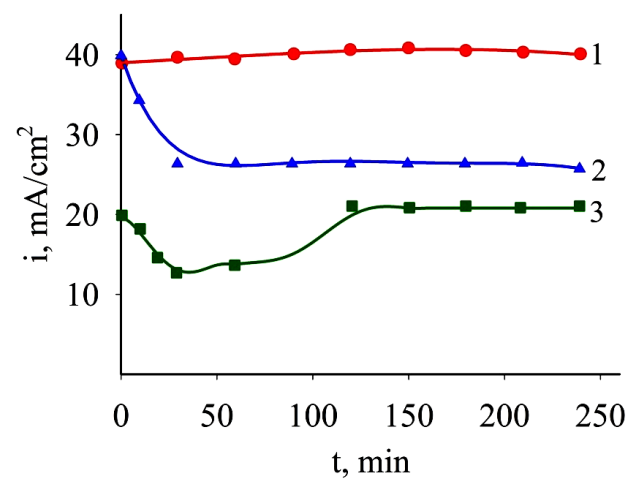

Fig. 5. Dependence of the total current density on the electrolysis time, measured on the oxide films containing

$\mathrm{Ti}(\mathrm{IV}) \mathrm{mol} / \mathrm{cm}^{2}: 1-0 ; 2-2.26 \cdot 10^{-8} ; 3-5.21 \cdot 10^{-8}$

A degree of the MTBE decomposition also depends on the concentration of alkali in the electrolyte (Table 4). The maximum value of decomposition degree corresponds to a concentration of the $\mathrm{KOH}$ solution of $0.5 \mathrm{~mol} / \mathrm{l}$. This is obviously due to the fact that the films with the largest content of $\mathrm{Ti}(\mathrm{IV})$ are formed under these conditions.

The highest corrosion resistance of films is achieved during formation of oxides from alkaline solution of the same concentration. Therefore, the $0.5 \mathrm{M}$ solution of $\mathrm{KOH}$ is optimal in order to enable stable and continuous operation of the $\mathrm{SnO}_{\mathrm{x}}\left(\mathrm{TiO}_{\mathrm{y}}\right)$ electrocatalytic films.
Table 4

Effect of $\mathrm{KOH}$ concentration on the degree of MTBE decomposition on a titanium-containing oxide film

\begin{tabular}{|c|c|c|c|}
\hline \multirow{2}{*}{\begin{tabular}{c} 
Degree of MTBE decomposition \\
\cline { 2 - 4 }
\end{tabular}} & \multicolumn{3}{|c|}{ KOH concentration, mol/l } \\
\hline $\begin{array}{c}\left(\mathrm{C}_{0}-\mathrm{C}\right) / \mathrm{C}_{0} \text { (over the first } 30 \mathrm{~min} \\
\text { of electrolysis) }\end{array}$ & 0.30 & 0.5 & 1.0 \\
\hline
\end{tabular}

\section{Conclusions}

1. We investigated effect of anodic tin treatment parameters in an alkaline solution on the composition of the formed oxide film. It was established that conducting the electrolysis in the presence of potassium metatitanate leads to the formation of the $\mathrm{SnO}_{\mathrm{x}}(\mathrm{TiOy})$ oxide mixture on the surface of tin. A twostage technique for the formation of oxide film at the electrode potentials of $-0.3 \mathrm{~V}$ and $3.0 \mathrm{~V}$ makes it possible to substantially increase the content of titanium oxide compounds in the oxide mixture. An analysis of the composition and protective ability of the $\mathrm{SnO}_{\mathrm{x}}\left(\mathrm{TiO}_{\mathrm{y}}\right)$ films revealed that films with a maximum content of titanium compounds and the largest corrosion resistance are formed at a concentration of potassium metatitanate above $1 \cdot 10^{-3} \mathrm{~mol} / \mathrm{l}$. Films with enhanced corrosion resistance are formed in the presence of $\mathrm{K}_{2} \mathrm{TiO}_{3}$ at a significantly lower alkalinity than without the addition.

2. The electrocatalyctic activity of the modified oxide films on tin is determined. It was found that increasing the content of titanium oxide compounds in a deposit contributes to the acceleration of anodic oxidation of MTBE. It is shown that this process takes place directly on the surface of the oxide film rather than during interaction with oxygen generated on the anode. The modified oxide films on tin with maximal corrosion resistance and electrocatalytic activity are formed from the solutions that contain $0.5 \mathrm{M} \mathrm{KOH}$.

\section{References}

1. El-Sherif, R. M. Mechanism of Corrosion and Corrosion Inhibition of Tin in Aqueous Solutions Containing Tartaric Acid [Text] / R. M. El-Sherif, W. A. Badawy // Int. J. Electrochem. Sci. - 2011. - Vol. 6. - P. 6469-6482.

2. Zhong, X. The corrosion of tin under thin electrolyte layers containing chloride [Text] / X. Zhong, G. Zhang, Y. Qiu, Z. Chen, X. Guo, C. Fu // Corrosion Science. - 2013. - Vol. 66. - P. 14-25. doi: 10.1016/j.corsci.2012.08.040

3. Gervasi, C. A. Electrochemical studies on the anodic behavior of tin in citrate buffer solutions [Text] / C. A. Gervasi, P. A. Palacios, M. V. Fiori Bimbi, P. E. Alvarez // Journal of Electroanalytical Chemistry. - 2010. - Vol. 639, Issue 1-2. - P. 141-146. doi: 10.1016/ j.jelechem.2009.12.002

4. Gervasi, C. A. Electronic Structure of Tin Passive Films and Its Influence on the Corrosion of the Base Metal [Text] / C. A. Gervasi, P. A. Palacios, P. E. Alvarez, M. V. Fiori-Bimbi, S. A. Brandan // Industrial \& Engineering Chemistry Research. - 2013. - Vol. 52, Issue 26. - P. 9115-9120. doi: 10.1021/ie4008216

5. Gervasi, C. A. Comparative cyclic voltammetry and SEM analysis of tin electrodes in citrate buffer solutions [Text] / C. A. Gervasi, P. E. Alvarez, M. V. Fiori Bimbi, M. E. Folquer // Journal of Electroanalytical Chemistry. - 2007. - Vol. 601, Issue 1-2. - P. 194-204. doi: 10.1016/j.jelechem.2006.11.019

6. Gervasi, C. A. Characterization of anodic tin passive films formed in citrate buffer solutions [Text] / C. A. Gervasi, M. V. Fiori Bimbi, P. E. Alvarez // Journal of Electroanalytical Chemistry. - 2009. - Vol. 625, Issue 1. - P. 60-68. doi: 10.1016/j.jelechem.2008.10.013

7. Tselesh, A. S. Anodic behaviour of tin in citrate solutions: The IR and XPS study on the composition of the passive layer [Text] / A. S. Tselesh // Thin Solid Films. - 2008. - Vol. 516, Issue 18. - P. 6253-6260. doi: 10.1016/j.tsf.2007.11.118

8. Palacios-Padrós, A. Tin passivation in alkaline media: Formation of $\mathrm{SnO}$ microcrystals as hydroxyl etching product [Text] / A. Palacios-Padrós, F. Caballero-Briones, I. Díez-Pérez, F. Sanz // Electrochimica Acta. - 2013. - Vol. 111. - P. 837-845. doi: 10.1016/j.electacta.2013.07.200 
9. Kwaśniewski, D. Electrochemical behaviour of tin in alkaline electrolyte [Text] / D. Kwa niewski, M. Grdeń // Electrochemistry Communications. - 2015. - Vol. 61. - P. 125-128. doi: 10.1016/j.elecom.2015.10.019

10. Wang, M. Preparation of nanoporous tin oxide by electrochemical anodization in alkaline electrolytes [Text] / M. Wang, Y. Liu, D. Xue, D. Zhang, H. Yang // Electrochimica Acta. - 2011. - Vol. 56, Issue 24. - P. 8797-8801. doi: 10.1016/j.electacta.2011.07.085

11. Lu, C. Tunable synthesis of nanoporous tin oxide structures on metallic tin by one-step electrochemical anodization [Text] / C. Lu, J. Wang, D. Meng, A. Wang, Y. Wang, Z. Zhu // Journal of Alloys and Compounds. - 2016. - Vol. 685. - P. 670-679. doi: 10.1016/ j.jallcom.2016.05.316

12. Kaizra, S. Electrochemical growth of tin(II) oxide films: Application in photocatalytic degradation of methylene blue [Text] / S. Kaizra, Y. Louafi, B. Bellal, M. Trari, G. Rekhila // Materials Science in Semiconductor Processing. - 2015. - Vol. 30. P. 554-560. doi: 10.1016/j.mssp.2014.10.045

13. Vargalyuk, V. F. Electrodeposition of tin in presence of $\mathrm{K}_{2} \mathrm{TiO}_{3}$ [Text] / V. F. Vargalyuk, E. A. Plyasovskaya, E. I. Nester // Visn. Dnipropetr. un-tu. Ser.: Khim. - 2016. - Vol. 24, Issue 1. - P. 7-12.

14. Sknar, Yu. E. Electrodeposition of Ni-ZrO2 Nanocomposites from Methanesulfonate Electrolytes [Text] / Yu. E. Sknar, N. V. Amirulloeva, I. V. Sknar, F. I. Danylov // Materials Science. - 2016. - Vol. 51, Issue 6. - P. 877-884. doi: 10.1007/s11003-016-9916-2

15. Danilov, F. I. Electrodeposition of nickel-based nanocomposite coatings from cerium(III)-ion-containing methanesulfonate electrolytes [Text] / F. I. Danilov, Yu. E. Sknar, I. G. Tkach, I. V. Sknar // Russian Journal of Electrochemistry. - 2015. - Vol. 51, Issue 4. - P. 294-298. doi: 10.1134/s1023193515040023

16. Danilov, F. I. Kinetics of electrodeposition of $\mathrm{Ni}-\mathrm{ZrO}_{2}$ nanocomposite coatings from methanesulfonate electrolyte [Text] / F. I. Danilov, Yu. E. Sknar, N. V. Amirulloeva, I. V. Sknar // Russian Journal of Electrochemistry. - 2016. - Vol. 52, Issue 5. P. 494-499. doi: 10.1134/s1023193516050037

17. Yu, Y. Platinum nanoparticles ion-implanted-modified indium tin oxide electrode for electrocatalytic oxidation of formaldehyde [Text] / Y. Yu, T. Wang, Y. Fu, W. Su, J. Hu // International Journal of Hydrogen Energy. - 2014. - Vol. 39, Issue 31. - P. 1761717621. doi: 10.1016/j.ijhydene.2014.08.149

18. Geiger, S. Stability limits of tin-based electrocatalyst supports [Text] / S. Geiger, O. Kasian, A. M. Mingers, K. J. J. Mayrhofer, S. Cherevko // Scientific Reports. - 2017. - Vol. 7, Issue 1. doi: 10.1038/s41598-017-04079-9

19. Vargalyuk, V. F. Electrochemical formation of SnxTi(1-x)O2 oxide film on tin [Text] / V. F. Vargalyuk, K. A. Plyasovska // Visn. Dnipropetr. un-tu. Ser.: Khim. - 2009. - Vol. 17, Issue 15. - P. 42-45.

20. Vargalyuk, V. F. Peculiarities of the electrooxidation of tin in alkaline medium [Text] / V. F. Vargalyuk, E. A. Plyasovskaya, A. S. Zamyatina // Ukrainian Chemistry Journal. - 2015. - Vol. 81, Issue 1/2. - P. 40-43. 